\title{
RELIGIOUS CURRICULUM IMPLEMENTATION: BETWEEN CHARACTER LEARNING, SPIRIT OF AND MODERNIZATION OF EDUCATION RELIGIOSITY MADRASAH IBTIDA'IYAH JAKARTA-PUSAT
}

\author{
10.34005/akademika.v8i02.548
}

\author{
Evi Sopandi \\ evi_sopandi@yahoo.co.id \\ Puslitbang Kementrian Agama Republik \\ Indonesia
}

\author{
Achmad Siswanto \\ achmadsiswanto@unj.ac.id \\ Pendidikan Sosiologi FIS-UNJ, Jakarta- \\ Indonesia
}

\begin{abstract}
Character education as a national education issue is actually not new if it is associated with the long history of the founding of the Indonesian nation. This study aims to describe the implementation of religious education curriculum in Madrasah Ibtida'iyah Istiqlal, Central Jakarta in shaping the character of students. This research uses a qualitative approach with a case study method. The research subjects were students, teachers, principals, founders of foundations, and parents of guardians at the Central Jakarta-Istiqlal Madrasah. Students here are those who are already in grades 4, 5 and 6 of elementary school. To strengthen the qualitative analysis, in-depth interviews were conducted with research subjects who were education principals practitioners, curriculum representatives, student representatives, and teachers in MI Istiqlal. Variations in the subject of this study are expected to be able to strengthen data and qualitative data analysis. The results of this study indicate that the character education that was initiated by MI Istiqlal Central Jakarta emphasizes intellectual, social-emotional, kinesthetic, and spiritual intelligence in children. The qualitative findings of this study also show that education at MI Istiqlal Central Jakarta is a reflection of Islamic education modernism. In this context MI Istiqlal uses technology-based learning.
\end{abstract}

Keywords: Religious curriculum, Education, Character

\section{INTRODUCTION}

The process of human learning in fact does not only occur through educational institutions, but also occurs when individuals are in the community. However, human education takes place in educational institutions, especially schools being an effective media in the production and reproduction of knowledge. This description can be related to the idea of Mutrofin which says that the education system in schools has various interests both socio-cultural, political, economic, and transformation interests (Mutrofin, 2009: 31-46).

At this level, the presence of school institutions with adequate curriculum guidance is a space that is provided in an integrated and structured manner 
to accommodate the learning process that is able to direct the community towards a better life. The importance of the relationship between the school and the curriculum to the future progress of the nation makes many people seriously examine the curriculum. So far many scientific studies have revealed the various impacts of the relationship between the formal education curriculum and various aspects of community life, both social, economic, political and cultural.

As pointed out by Apple (1991) that the school education curriculum can be used by the authorities as a means of social control of society for the socio-political interests of the authorities. According to Apple, the curriculum element in the school education system is an effective medium for the sociopolitical interests of the authorities (Apple, 1991: 6). In practice this is carried out through textbooks and curriculums which are the basis for learning in schools.

For example, Japan makes textbooks taught in schools a channel for reconstructing stories about trade and occupation invasions of China and Korea (Apple, 1991: 7). This presentation is an illustration of how Japanese ruling politics strengthened political and economic domination of China and Korea as a theme of positive social control in textbooks taught in schools for the political interests of Japanese rule. In this context, Japan uses the issue to motivate its people to have a fighting spirit, a spirit of learning, and encouragement to always develop Japan as a developed country.

Other studies that seek to look critically at the function of the curriculum in the realm of community life can be found in the study of Rahmat Hidayat (2008) entitled Curriculum as a Contestation of Power: a Critical Discourse Analysis of the Sociology Curriculum and Sociology Textbooks based on the 2006 \& 1984 Curriculum. The discussion was focused on efforts to uncover dominant discourses in the high school sociology curriculum and sociology textbooks based on the 2006 and 1984 curriculum.

Using Bourdieu's perspective, the study above shows some interesting findings related to dominant discourse such as social order, modernization, and development distributed by dominant groups. in the exercise of his authority in the realm of education. For example in this study it was revealed about how the political stability initiated by the New Order government in various dominant discourses was instilled by him through a set of rules, and the value of systematic texts in the curriculum (Hidayat, 2008: 86-87). Based on these findings, basically these discourses relate to the politics of state power that makes education systems and practices an effective channel to support political stability, economic growth and reduce all forms of conflict that occur in the community.

157 IAkademika Jurnal Teknologi Pendidikan Vol. 8 No. 2 
Different from the studies described above, there is one study that seeks to reveal the positive role of the curriculum in the positive life of students in society. For example, a study conducted by Seda (1987), who sought to critically reveal the positive role of a hidden curriculum that serves to instill the values of modernity life and improve student achievement in educational activities in schools.

Relying on studies that have been described above in essence emphasizes that the curriculum has a function to accommodate the segmentation of knowledge taught in formal schools. In this context the formal school curriculum must be in accordance with the needs of the community that continues to run and develop dynamically.

Education discourse in Indonesia cannot be separated from religious aspects. Herein lies the role of Islam in education continues to experience growth as well as expansion since Indonesia under Dutch Colonialism, postindependence (old order), new order, post-reformation, and to this day. So it cannot be denied that the modernization of Islamic education continues to run and develop in tune with the national education system.

The growth of religious-based schools is not only established by religious mass organizations (NU and Muhammadiyah). But there are also Islamicbased public schools that stand independently and are not under the auspices of certain mass organizations. This Islamic public school was established with the label of an Islamic education foundation that carried out its function to educate the public. As suspected by Azra, the growth of schools labeled with Islam as a result of the rise of Islam (Azra, 2012; Hefner, 2000: 13).

In general, previous studies on the relationship between curriculum, school and various aspects of social life have been carried out by various groups both by Apple (1991), Hidayat (2008) and Seda (1987). Specifically, they study curriculum in the macro realm, and narrow curriculum studies in the realm of political economy and modernity values. While this study seeks to see how the implementation and contribution of religious curriculum in Islamic schools in realizing character learning based on religious values in the discourse of education modernization. From this explanation, the problems in this study are: 1). How is the implementation of character education based on religious values carried out by the school in the learning process? 2). How is character education implemented and realized through the practice of religious religiosity-based curriculum in schools? 3). What is the contribution and relevance of character education in the context of Madrasah Ibtidaiyah (MI)?

\section{METHOD}


This study uses a qualitative method (Newman, 2010:9-10) to analyze the implementation of character education in the religious curriculum in Madrasah Ibtidaiyah Istiqlal Jakarta-Pusat. This approach was chosen so that this study would get a detailed picture of an empirical analysis of the reality and implications of the religious curriculum in improving the quality of education, especially in shaping the character and spirit of religious values in the learning process. The research subjects were students, teachers, principals, founders of foundations, and parents of guardians in the Central Jakarta-Istiqlal Madrasah. Students here are those who are already in grades 4,5 and 6 of elementary school. In order to strengthen the qualitative analysis, in-depth interviews were conducted with research subjects who were education practitioners, principals, curriculum representatives, student representatives, and teachers in MI Istiqlal. Variations in the subject of this study are expected to be able to strengthen data and qualitative data analysis.

\section{FINDING}

\section{The Contribution of Islamic Education in the National Education System Education}

Discourse in Indonesia cannot be separated from the religious aspects of precolonial times until the advent of colonialism. Undeniably religious groups, especially Islam, have played an important role in the realm of people's lives, especially in the aspect of education. Long before the school education system existed, religious-based education was present earlier to fill the needs of the community. Based on several studies of Javanese society in Hinduism, Buddhism, and Islam since the beginning it has a characteristic style of religious education manifested in the form of huts and boarding schools (Soemardjan, 2009: 403; Gertz in Hefner, 2009: 5). Thus, the role of Islam in education has continued to develop and expand since Indonesia under Dutch colonialism. So at that time, the ideology of Islamic teaching practices had spread in several parts of Indonesia from West Java, Central Java, Aceh and Minangkabau (Steenbrink, 1994:8).

Specifically, evidence of Islam in the realm of education can be seen in 1925, Muhammadiyah has actively carried out educational social movements through 8 teacher schools in Yogyakarta, 32 five-year schools and 14 madrasas with a total of 4000 students educated by 119 teachers (Noer, 1996: 95). As for other community organizations that take part in the realm of education can also be seen through the educational movement carried out by the Islamic Union (Persis). Exact contributions in the realm of education 
began between 1930 and 1932 by establishing several schools ranging from kindergarten to (kindergarten) to a teacher's school (Noer, 1996:101).

No different from Islam in the colonial period, Christianity also had a contribution to the dynamics of Indonesian education with the mission of Zending (Steenbrink, 1994). Even though there was a demarcation between Islamic education and general Western education at the time, still the contribution of Islam in the national education system was so important, so that the role of Islam in the national education system cannot be ruled out after being freed from colonization. It is this historical setting that makes Islamic education find its momentum to contribute to the nuances of Islam in the national education system.

The initial phase of the founding of a new state under the old order regime of national education policy was boarded by two interest groups. First, groups that have ideological interests and perspectives for the construction of secular national education, namely secular nationalists. Second, groups dominated by religious nationalists who insist that the state must adhere to a religious model in the national education system (Sirozi, 2004:41-42). In response to this situation, Indonesia finally adopted a "dual" system in the national education system. The picture can in some views be understood as an effort to reconcile the conflict between the two opposing camps. So that the management of religious and general education systems throughout the country is known as "general" education is managed by the Ministry of Education and Culture (now the Ministry of National Education) and "religious" education is managed by the Ministry of Religion (Kemenag).

Islamic education in the historical stage of the national education system is strongly influenced by the national political constellation. In the new order era, the relationship between Islam and the state was running harmoniously, as a result Islamic-based schools were once discriminated against, because the relationship between Islam and the state in the political sphere at that time was feared to be a political force that could rival the state (Alfian, in Thaba, 1996:243 ). Even though it was treated unfairly, Islamic-based educational institutions in the political journey of the New Order ultimately enjoyed a surplus of education management. This can be seen from the efforts of the government in the 70s to issue 3 ministerial SKBs (Minister of Education and Culture, Minister of Religion, and Ministry of Home Affairs) that the curriculum for Madrasah Aliyah Negeri (MAN) is adjusted to the curriculum of High School (SMA). The original MAN curriculum contained $70 \%$ of religious subjects and $30 \%$ of general subjects replaced to $70 \%$ of general subjects and 30\% of religious subjects (Sirozi, 2004:43;).

The state's acceptance of Islam improved in the mid-1980s, which was marked by the New Order's attention to the increasing Islamic awakening. This situation has implications for government attention in Islamic activities in 
the public sphere between 1988 and 1993 which included providing space for Islam to establish an Islamic Bank, expanding the authority of Islamic courts, revoking the ban on the use of headscarves in public schools, establishing Islamic newspapers, eliminating gambling, an increase in Islamic broadcasting programs on TV, and specifically the government is working to increase funding for Islamic schools and mosque construction (Hefner, 2000: 14-16).

In addition to the above, the strengthening of state acceptance of Islamic education is demonstrated through the introduction of the 1994 curriculum which made more than $80 \%$ of the MAN curriculum equal to the public school curriculum equivalent to SMA, which distinguishes between MAN and SMA only lies in MAN given permission to give 7 hours in 1 week of religious studies as extracurricular activities covering Arabic, AL Qur an and Hadith and the history of Islamic civilization (Sirozi, 2004: 43; Thaba, 1996:335).

The equal status and treatment of Islamic-based education with public schools at the end of the New Order government enabled the flourishing of Islamic-oriented schools in the country. The flourishing of religious based schools is not only established by religious mass organizations. But there are also Islamic-based public schools that stand independently and are not under the auspices of certain mass organizations. This Islamic public school was established with the label of an Islamic education foundation that carried out its function to educate the public. As suspected by Azra, the growth of schools labeled with Islam as a result of the rise of Islam (Azra, 2012). Meanwhile, according to Hefner Muslim intellectuals just occupying the middle class in the decades between the 1970s and 1980s is calling for attention to focus on education, the state bureaucracy and businesses that supported the state (Hefner, 2000:13)

As a result of continued improvement in the relationship between Islam and the state can be seen throughout the New Order so many public schools with Islamic nuances have sprung up, from ordinary Islamic public schools to leading schools or Islamic favorite schools. Islamic public schools were originally ordinary public schools and without leading labels. Metamorphosis of Islamic schools to be excellent schools, is the result of improving the quality of education quality and is strongly supported by adequate funding (Azra, 2012; Lubis,2008; Supiana 2008). The pre-eminent school or favorite school of Islam is termed by Azra as anschool elite Muslimwhich has transformed the role of Islamic education from an orientation to Islamic sciences to an educational institution that orientates its education on mastery as well as the achievement of science and technology (Science and Technology) (Azra,2012).

161 IAkademika Jurnal Teknologi Pendidikan Vol. 8 No. 2 
In the present context, the flagship Islamic schools have flourished at every level of the education unit, both at the elementary (elementary) level, junior high school (SMP), and senior high school (SMA). This flagship Islamic school offers a fusion of religious-based education systems, especially Islamic values with the general education system. Both aspects are implemented in an integrated manner in the learning process at school. The learning process was carried out at the Madrasah Ibtidaiyah (MI) Istiqlal, Central Jakarta. MI Istiqlal Central Jakarta implements a religious science learning system that is integrated in general science education.

\section{Historical Context, Vision-Mission, and Purpose of MI Istiqlal Establishment in Central Jakarta}

Historically the institutionalization of Islamic education within the Istiqlal mosque in Central Jakarta cannot be separated from the struggle of a figure named Mrs. Nibras Oedin Rahmani Salim. She is a female figure who has a serious concern in the development of early childhood education which is based on the values of Islamic teachings. He realized this reality by establishing a formal educational institution in the Istiqlal mosque located in Pasar Baru Village, Sawah Besar District, Central Jakarta. The spirit of establishing educational institutions within the mosque is motivated by its desire to contribute to advancing national education.

The initial phase of establishing a formal educational institution by Nibras did not go smoothly. He was rejected by three ministers of religion when he wanted to propose the establishment of an educational institution within the Istiqlal mosque. The rejection of the establishment of this educational institution was based on the reason that the Istiqlal mosque was a state mosque which was prioritized only for places of worship. In addition, this rejection was also backed up by the results of an annual evaluation of the swelling of funds for mosque operations, mainly in terms of water and electricity usage. Thus, the rejection of the establishment of formal education was motivated by the worry of the mosque management if an educational institution was built it would add to the burden of mosque operational funding (interview with Drs. Khasmudi, October 2014).

The challenges facing Nibras in establishing a formal educational institution within the mosque did not relax her intention to continue to establish a formal school within the Istiqlal mosque. Nibras slowly tried to convey, and assured that the concept of the mosque was not merely a place of worship. On the contrary, the actual conception of the mosque is very integrated with various aspects of community life such as social, economic, political, cultural, and educational. As the life story of the Prophet who made the mosque as a source, and the center of community development in various aspects of life. 
Based on the hard work and commitment of Mrs. Nibras to establish an educational institution, finally the Minister of Religion Dr. Maftuh Basyumi, MM gave a policy to develop education in the Istiqlal mosque. The momentum was used by Ms. Nibras to establish play groups and raudhatul athfal (RA). The two institutions were established on July 26, 1999. The learning process in these two institutions can be considered successful. The reality was conveyed by a senior teacher named Drs. Khasmudi who said that the first educational institution for play groups and RA was established had been flooded with students from various diverse socioeconomic circles (Interview with Drs. Khasmudi September 2014).

The success of educational institutions for playgroups, and raudhatul athfal, which was founded by lbu Nibras, is marked by the number of students enrolling in the institution that continues to grow each year. As stated by brother Ramli, SH (Chairperson of the Istiqlal MI Committee), who said that in the past five years in a row, educational institutions playing groups and RA continued to increase the number of students who registered themselves, so that the institution was unable to accommodate students to study and playing in the playgroup and RA Istiqlal (interview with Ramli, SH October 2014). After successfully establishing a play group and raudhatul athfal (kindergarten level), the figure of Nibras was not complacent. He kept trying to develop, and establish educational patterns in the two institutions.

In anticipation of the progress of educational patterns in institutions of playgroups and raudhatul athfal, Ms. Nibras did not hesitate to conduct a comparative study of the pattern of kindergarten education in Tallahassee Florida, United States. He conducted this comparative study to develop educational patterns in the two institutions he established in the Istiqlal mosque. After returning from the comparative study, Mrs. Nibras had the intention to establish a more complete level of education unit (- from the Play Group, Raudhatul Athfal (RA), Madrasah Ibtidaiyah (MI), Madrasah Tsanawiyah (MTs), and Madrasah Aliyah (MTs) MA)

The urge to establish a complete education unit level was strengthened when parents of parents urged Nibras to immediately establish the level of education units from elementary to senior high (MI, MTs, and MA), so that in 2004 was an important moment for the establishment of the MI Istiqlal educational institution, and a new round for the establishment of more complete levels of the education unit level

Table 1. Establishment of Education Unit in the Istiqlal Mosque in Jakarta-Central 163 IAkademika Jurnal Teknologi Pendidikan Vol. 8 No. 2 


$\begin{array}{clc}\text { No } & \begin{array}{l}\text { Type of Educational Unit } \\ \text { and Supporting Activity } \\ \text { Unit for }\end{array} & \text { Year Stand } \\ 1 & \text { Group } & 19991999 \\ 2 & \text { raudhatul athfal (RA) } & 1999 \\ 3 & \text { Madrasah Ibtida'iyah (MI) } & 2004 \\ 4 & \text { Madrasah Tsanawiyah } & 2007-2008 \\ 5 & \text { (MTs), } & 2011-2012\end{array}$

The initial phase of the formation of the study group was only between 10 and 15 people. The recitation activity at that time was carried out in a simple place namely the car garage owned by Haji Mohammad Syarif.

\section{Towards Modernization of Character Education with Islamic Teaching}

Education is a long-term learning process to become a developing human being so as to be able to actualize all of its potentials and to become quality human beings in accordance with the demands of the times and to benefit everyday life in society. It is education that sows the seeds of culture and human civilization that live and are lived by the values of a vision that develops and is developed in a society. Therefore, education by itself must be anticipatory, but that does not mean that the education process only follows the development trends that are happening in the community but education must be able to change the development trends that occur for the better.

The development of the national education system is an effort aimed at realizing a quality, advanced, independent and modern Indonesian society. Educational development is an important part of a comprehensive and earnest effort to improve the nation's dignity. Success in developing education will make a major contribution to the achievement of overall national development goals. Based on this, the development of education covers a wide range of dimensions and is organized as a systematic whole with an open and multi-meaning system.

In order to realize this order, strategic and integrated efforts were made to support education. The opportunity to obtain quality education applies to all (education of all), starting from early childhood education to higher education.

\section{Pattern of Character Education in MI Istiqlal}

Developing the quality of human resources as early as possible in a directed, integrated and comprehensive manner through various proactive and reactive efforts by all components of the nation so that the younger generation can develop optimally accompanied by the right to support and the environment in accordance with their potential. 


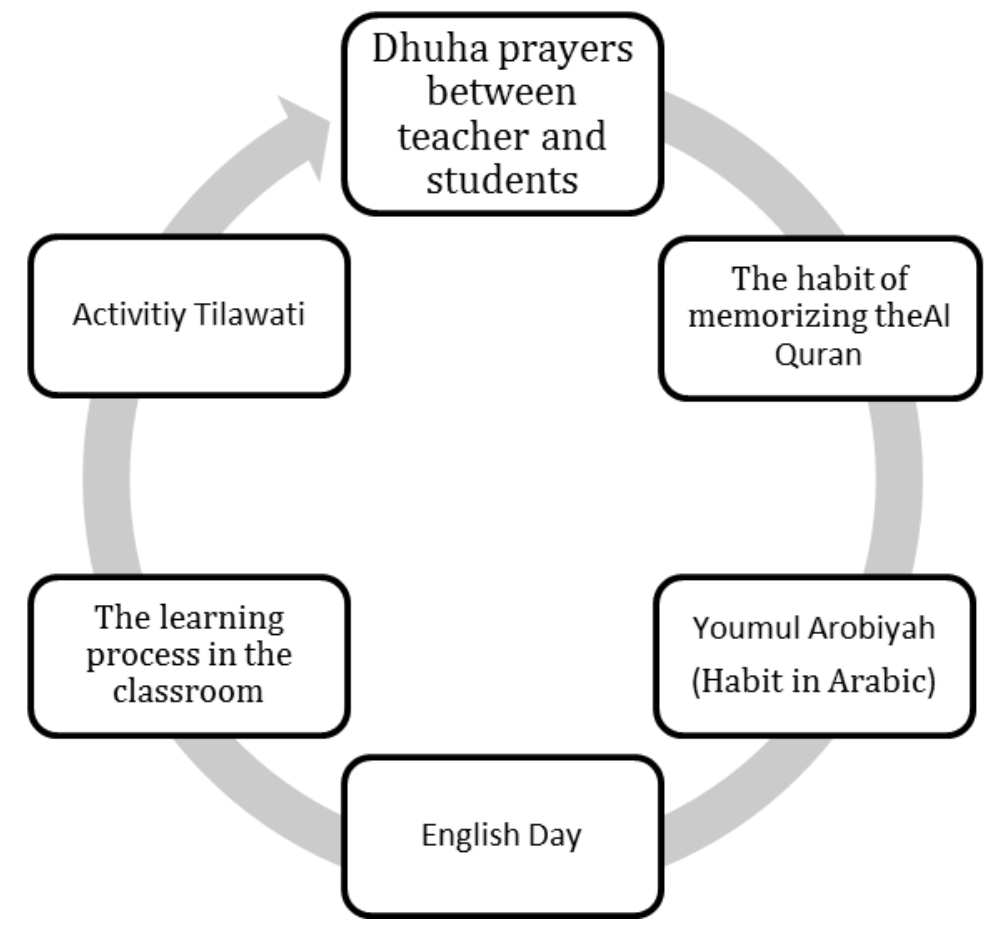

\section{Classroom Learning: Synergy between the Religious Curriculum and the General Curriculum}

Educational institutions such as school organizations are institutional frameworks in which the administration of education can play a role in managing the organization to achieve its stated goals. Viewed from the levels of an organization in this case the school, education administration can be seen in three levels, namely the institutional level (Institutional level), managerial level (managerial level), and the technical level (Murphy and Louis, 1999). The institutional level relates to the relationship between educational institutions (schools) with the external environment, managerial levels related to leadership, and institutional organizations (schools), and technical levels related to the learning process. Thus the management of education in the context of educational institutions has a broad scope, besides that the fields that must be handled are also quite a lot and complex from the start of physical, financial, and human resources involved in the educational process activities in schools

According to the Consortium on Renewing Education (Murphy) and Louis, ed. 1999: 515) Schools (educational institutions) have five forms of capital that need to be managed for educational success, namely: 
1. Integrative capital

2. Human capital

3. Financial capital

4. Social capital

5. Political capital

Then integrative capital is capital related to the integration of the other four capital to be used for the achievement of programs / educational goals, human capital human resources whose ability to use knowledge for the benefit of the education / learning process, financial capital is the funds needed to run and improve the educational process, social capital is i the beliefs and habits that describe the school as a community, and political capital are the basis of the legal authority they have to carry out the education / learning process.

\section{CONCLUSIONS}

The results of this study also show that character education initiated by MI Istiqlal Central Jakarta emphasizes intellectual, emotional-social, kinesthetic, and spiritual intelligence in children. Intellectual intelligence is instilled by MI Istiqlal through the study of religious and general science. MI Istiqlal also requires its students to reprimand one another with other students. These efforts are carried out as a way to train children's social and emotional intelligence. Furthermore, for kinesthetic intelligence, Ml istiqlal provides a variety of sports such as football, basketball, and swimming sports. Various types of sports are facilitated by tutors who have a reputation in the field of sports.

Intellectual, emotional-social, and kinesthetic intelligence alone are not enough to create a superior generation. Therefore MI Istiglal also guides their students to have spiritual intelligence. This spiritual intelligence is explored and built through the school culture, which consists of, compulsory prayers on time, praying in congregation, memorizing the verses of the Holy Qur'an, tilawati Al Qur an, Arabic and English speaking culture. The culture of the school is not only done by students, but the principal, teachers, and other school residents also do the culture. For example when the Duha prayer is taking place, all teachers and principals must pray together with the students.

The qualitative findings of this study also indicate that education at $\mathrm{MI}$ Istiqlal in Central Jakarta is a reflection of Islamic education modernism. In this context Ml Istiwlal uses technology-based learning. So, the learning process of students at MI Istiqlal is always integrated with the use of technology (LCD Projectors, Language Labs, Computer Labs complete with internet facilities). Although students' learning is integrated with technology, students at MI Istiqlal are strictly forbidden to bring mobile phones and pocket 
money. This was backed up because MI Istiqlal had prepared a lunch package, which was ready to be eaten together between the teacher and students.

Character education as a national education issue is actually not new if it is associated with the long history of the founding of the Indonesian people. We can learn from Sukarno as the nation's founding father, how he instilled and implemented the values of the character of independence and freedom of thought in the nation. He can be an example in educating the nation to stand on the character of independence, especially to believe in oneself, and freedom of thought through direct communication through various speeches.

Learning that is thick with the nuances of character values is not only a cognitive food for students and students, teachers must exert influence to be the social practice of the lives of all learning citizens based on those character values. Efforts to integrate curriculum structure, learning culture, and thickening of character values in social practices of life of all learning citizens reciprocally can be a massive reinforcement of character values in the culture of student behavior, both in school and outside of school. Thus education can be an institution that can contribute in building morals for civilized Indonesia. Based on the presentation conclusions of this research, several suggestions can be raised in order to strengthen character education based on the modernization of Islamic education as follows:

- Strengthening textbooks that contain character values as guidelines for student and teacher learning in the school arena.

- Schools need to provide outbound or field trip programs to students. This activity aims to strengthen and train the students' struggle, commitment and consistency.

Provide opportunities for teachers to continue their studies to a further level (S2) to increase their capacity. This goal is carried out in order to improve the ability of teacher human resources, so that the achievement of character education can be achieved to the maximum in

\section{BIBLIOGRAPHY}

Abdullah's. (2009). Curriculum Development: Theory and Practice. Yogyakarta: Ar-Ruzz.

Apple W Michael, et al (ed). (1991). The Politics of The Textbook. New York: Routledge. 
Azra, Azyumardi. (2012). Islamic Education: Tradition and Modernization in the Middle of the Third Millennium Challenge. Jakarta: Kencana Prenada Media Group.

Hasibuan Lias. (2010). Curriculum and Educational Thinking. Jakarta: Gaung Persada.

Hefner W. Robert. (2000). Islamic Justice Market: Local Articulations of Capitalism and Democracy. Yogyakarta: Lkis. In Southeast Asia. University of Hawai'I Press.

Mutrofin. (2009). Why They Don't Go to School: An Evaluation of the Learning Obligation Program. Laksbang Presindo.

Rahmat Hidayat. (2011). Introduction to Sociology of the Curriculum. Jakarta: Rajawali Press.

Dan Hidayat, Rahmat. (2008). Curriculum as a Power Contestation: Critical Discourse analysis of the Sociology Curriculum and High School Sociology Textbooks Based on the 2006 Curriculum and the 1984 Curriculum. Thesis, Department of Sociology of Post-Graduate University of Indonesia.

Sanjaya, Vienna. (2011). Curriculum and Learning Theories and Practices of Educational Unit Level Curriculum Development (SBC). Jakarta: Kencana ...

Seda, Francisia SSE. (1987). Covert Curriculum and Individual Modernity (A Case Study Regarding Schools as Socialization Agents, Thesis of Sociology, FISIP UI, Jakarta.

Tilaar, HAR. (2006). National Education Standardization: A Crunchy Review. Rineka Cipta: Jakarta

Weis, Lois, at all (ed). (2006). Ideology Curriculum, and The New Sociology of Education: Revisiting the Work of Michael Apple, New York: Routledge. 